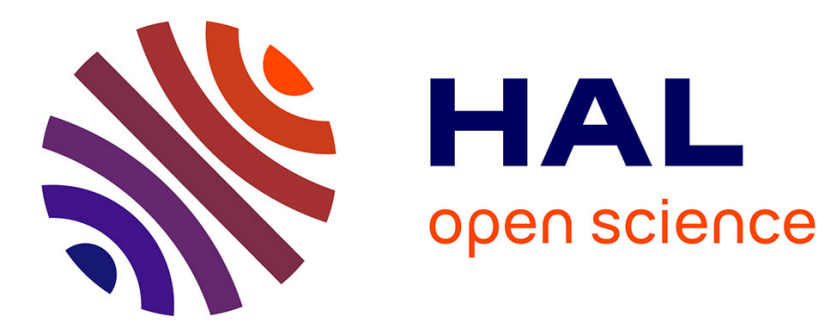

\title{
A nutritional dilemma: fish consumption, mercury exposure and growth of children in Amazonian Bolivia
}

Eric Bénéfice, S. J. Luna Monrroy, Ronald Lopez Rodriguez

\section{To cite this version:}

Eric Bénéfice, S. J. Luna Monrroy, Ronald Lopez Rodriguez. A nutritional dilemma : fish consumption, mercury exposure and growth of children in Amazonian Bolivia. International Journal of Environmental Health Research, 2008, 18 (6), pp.415-427. 10.1080/09603120802272235 . ird-00353651

\section{HAL Id: ird-00353651 \\ https://hal.ird.fr/ird-00353651}

Submitted on 16 Jan 2009

HAL is a multi-disciplinary open access archive for the deposit and dissemination of scientific research documents, whether they are published or not. The documents may come from teaching and research institutions in France or abroad, or from public or private research centers.
L'archive ouverte pluridisciplinaire $\mathbf{H A L}$, est destinée au dépôt et à la diffusion de documents scientifiques de niveau recherche, publiés ou non, émanant des établissements d'enseignement et de recherche français ou étrangers, des laboratoires publics ou privés. 


\title{
A nutritional dilemma: fish consumption, mercury exposure and growth of children in Amazonian Bolivia
}

\author{
Authors: Eric Benefice ${ }^{\text {a. Selma J. Luna Monrroy }}{ }^{\text {; }}$, Ronald W. Lopez Rodriguez ${ }^{\text {c }}$ \\ Affiliation a IRD (Institut de Recherche pour le Développement), Unit 024, Epidemiology and \\ s: $\quad$ Prevention, Vientiane, Lao PDR \\ ${ }^{\mathrm{b}}$ SELADIS, Facultad de Ciencias Bioquimicas y Farmacéuticas, Universidad Mayor \\ de San Andrès, La Paz, Bolivia \\ ${ }^{c}$ IRD, UR024, Epidemiology and Prevention, La Paz, Bolivia
}

DOI: $10.1080 / 09603120802272235$

Publication Frequency: 6 issues per year

Published in: International Journal of Environmental Health Research, Volume .$/$ title $\sim$ content $=\mathrm{t} 713425582 \sim \mathrm{db}=\mathrm{all} \sim \mathrm{tab}=\mathrm{issueslist} \sim$ branches $=18-\mathrm{v} 1818$, Issue 6 December 2008 , pages $415-427$

\section{Abstract}

To study associations between nutritional status and mercury exposure among communities of the Beni River. Cross-sectional survey of mothers and their children from 15 riverside Amerindian communities in the Beni River valley (Amazonian Bolivia). Hair mercury content $(\mathrm{H}-\mathrm{Hg})$ served as a bioindicator of mercury exposure. A total of 556 people were measured. Anthropometric indices of nutrition were calculated after measurements of stature, weight, arm circumference and subcutaneous fat folds. Indicators of lifestyle were collected: subsistence activity, fish consumption and ethnicity. The median of $\mathrm{H}-\mathrm{Hg}$ was equal to $4.0 \mu \mathrm{g} / \mathrm{g}$ (CI 95\%: 3.6 4.4). There existed a significant relationship between $\mathrm{H}-\mathrm{Hg}$ and nutritional indices in 5- to $10-$ year-old children $(\mathrm{F}=12.1 ; p<0.0001)$ but not in other age groups. Fishing activity, fish consumption and ethnicity had an effect upon the variance of $\mathrm{H}-\mathrm{Hg}$. Positive relationships between nutritional status and $\mathrm{H}-\mathrm{Hg}$ may be related to the high nutritional value of fish. Among women, the relationship between $\mathrm{H}-\mathrm{Hg}$ and nutritional status was negative $(\mathrm{F}=7.1 ; p<0.001)$, but this disappeared when ethnicity and subsistence activity were taken into account. In these Amazonian communities, recommendations aimed at lowering fish consumption to prevent mercury exposure should be balanced against nutritional advantages conferred upon growing children.

Keywords: hair mercury content; nutritional status; growth; fish consumption; Amerindians 


\section{Introduction}

From the mid-1970s on, a gold rush took place in the Amazonian basin, causing discharge of huge quantities of mercury into the atmosphere and waters (Malm et al. 1995). Roughly 130 tons of mercury was released each year for extracting about 90 tons of gold. Under favorable conditions existing in the aquatic environment, mercury can be converted into a potent neurotoxin: methyl mercury $(\mathrm{MeHg})$. Eventually, $\mathrm{MeHg}$ bio-accumulates within aquatic organisms and biomagnifies, passing from one trophic level to another (United Nations Environment Program [UNEP] 2002). The general population is contaminated through consumption of tainted fish. The role of gold mining in intoxication of such populations has been recognized since the 1990s (Branches et al. 1993; Malm et al. 1995). Lowland Bolivia has also been affected by this problem. Mercury contamination of the Beni River was recently reported (Maurice-Bourgoin and Quiroga 2002). It is worth mentioning that the Beni River contributes to the formation of the Madeira River, an important tributary of the Amazon.

Mercury contamination poses a serious nutritional problem, since fish consumption is an important source of animal foods for riverside communities (Benefice et al. 2006). A review of the literature on the diet of Amazonian Indians indicates that tubers (Manihot esculenta) and plantain (Musa paradisiaca) constitute staple foods, while fish provide high quality protein (Dufour 1991). Thus, any advice aimed at reducing or avoiding fish consumption may have drastic nutritional consequences and might also disturb the social organization and ecological subsistence system of Amerindian communities (Wheatley and Wheatley 2000). When confronted with mercury contamination, it should be pointed out that the flesh of certain fish is rich in polyunsaturated fatty acid (PUFA), especially omega-3 fatty acid required by membranes of photoreceptor cells and synaptogenesis of the developing brain (Simopoulos 1991). It is also recognized that PUFA play an important role in ensuring normal growth, cell functioning and prevention of degenerative and inflammatory diseases (Simopoulos 1991). In addition, fish have other nutritional advantages, and their consumption was recently proposed to prevent vitamin A, zinc and iron deficiencies in a community-based intervention (Roos et al. 2007).

Living conditions in the Amazon are often considered to be precarious, with a negative impact upon health. However, analyses indicate that while growth retardation is frequent during childhood, suggesting a state of chronic malnutrition, cases of severe and acute malnutrition are more rare (Dufour 1992). The heavy burden of infectious and parasitic diseases must also be taken into account to explain such a delay in growth (Ribas et al. 2001; Buitron et al. 2004; Foster et al. 2005). A well-balanced diet is necessary, and fish consumption is essential (Dorea 2003). It could thus be hypothesized that in disadvantaged Amazonian communities, subjects exposed to mercury after ingestion of fish may paradoxically present a better state of nutrition and a more favorable growth profile than non-contaminated subjects.

The present study was performed in the Beni River valley (lowland Bolivia), an area affected by intense gold mining and where mercury contamination of water, sediments and fish has been demonstrated (Maurice-Bourgoin et al. 2000). We also previously documented a mediocre state of health and nutrition in children from riverside communities (Benefice et al. 2006). Hence, the aim of this paper was to analyze and discuss possible associations between mercury exposure and nutritional status in a group of children and their mothers living on the banks of the Beni River. 


\section{Subjects and methods}

\section{Study context}

A multidisciplinary team was formed to study the methylation process of mercury in the flood plains of the Beni River and its impact on riverside populations. Within this framework, a survey on health, nutrition and mercury exposure from the Andean foothills to $120 \mathrm{~km}$ downstream was performed from March to August 2004.

\section{Subjects and sampling}

Among the 14,000 inhabitants living in the study area at the time of the 2001 census, only 4,000 actually lived along the river bank. The exact number is difficult to ascertain because some communities were either not recorded or were recorded as living in inland hamlets. Since the survey considered the risk in the general population, rather than the professional risk, we decided to include only mothers and their children. The rationale for this choice was that prenatal mercury contamination could severely impair cerebral development of infants due to the capacity of methyl mercury to cross the placenta barrier (Gilbert and Grant-Webster 1995). The mercury exposure study was performed during a nutritional survey (Benefice et al. 2006). Hence, sampling was carried out on the basis of a $35 \%$ expected prevalence of chronic malnutrition in the area among 0 to 10 -year-olds. A total of 364 children needed to be incorporated in order to achieve $5 \%$ precision with a $95 \%$ confidence interval. In all, 354 children were examined, giving adequate precision. Each mother and child present at the site during the visit was examined.

\section{Ecological and cultural setting}

The area under study is part of the northern Amazon region of lowland Bolivia. This region has a tropical climate with an annual rainfall ranging from $1800 \square 2200 \mathrm{~mm}$. It is a vast area encompassing 10 million hectares with a population of around 170,000 inhabitants. Vegetation is homogenous and exuberant. Tropical rainforest covers $70 \%$ of the surface.

Natives of the northern Amazon share various cultural traits with indigenous populations of southeastern Peru and northwestern Bolivia. Their contemporary history emerged with the founding of the Franciscan missions in Apolobamba during the seventeenth century. This area is peopled by two ethnic groups. The largest is formed by the Tacanas, while the smaller group is made up of a closely related tribe, the Ese Ejjas.

The Tacana population is made up of around 3400 inhabitants according to a recent census based on self designation (Anónimo 2005). However, only 500 persons speak the Tacana language. They are mainly farmers who grow maize, rice, tubers (cassava roots), plantain and bananas. They practice a system of slash and burn to cultivate pieces of land that can attain 1 ha. They obtain a substantial part of animal foods from hunting and fishing. They are well integrated into the Bolivian society and are involved in the market economy. The majority of Tacanas speak Spanish and are able to read and write.

The Ese Ejjas form the second group. They were decimated at the beginning of the twentieth century due to enslavement by rubber operators, epidemic diseases and inter-clan wars. They are believed to currently number $600 \square 700$ members. The clan living in the study area was 
constituted by about 200 people. Few adults have gone to school or speak Spanish and they continue to use their vernacular language. Their productive activities are mostly oriented towards use of river resources (fishing, collecting tortoise eggs). They also cultivate tubers, rice and plantain but in smaller parcels than the Tacanas. They have preserved a semi-nomadic traditional way of life, following the migration of fish and returning to their village during the flooding period.

\section{Health characteristics}

According to a previously published paper, the health and nutritional status of the population is mediocre (Benefice et al. 2006). Only two small hospitals exist in the area, and there are no health centers in these communities. About $70 \%$ of women surveyed gave birth alone. Some $50 \%$ had lost at least one child. The prevalence of anemia among women was high: $42 \%$ (confidence interval (CI) 95\%: $34.6 \square$ 49.8\%) presented moderate to severe forms. Chronic malnutrition was frequent in preschool children: 41\% (CI 95\%: 33.9-49.0\%) were affected. Intestinal parasitism was also prevalent in children: $85.2 \%$ (CI 95\% $80.7 \square 89.0 \%$ ) housed helminths and $68.2 \%$ (CI 95\% $62.6 \square 73.4 \%$ ) protozoans. About $30 \%$ of the children suffered from dermatitis, including pyodermitis, scabies, impetigo and lice. Common infections such as conjunctivitis, pharyngitis and rhinitis were also frequent (about $20 \%$ of the children). Simple diarrhea was frequently reported by mothers ( $20 \%$ of responses).

\section{Ethical considerations}

The study protocol was approved by the Comité Nacional de Bioética de Bolivia and by the Comité Consultatif de Déontologie et Bioéthique (IRD, France). Subjects or their parents were individually informed and they or their parents signed an informed consent form. Subjects participated willingly in the study and did not receive a salary or compensation. Results related to hair mercury content $(\mathrm{H}-\mathrm{Hg})$ were provided at the end of the study, with explanations and recommendations. Infested children received antihelminth or protozoan treatment and anemic women received a three-month dose of ferrous iron and folate. On a few occasions, severely ill subjects were conducted to the nearest hospital.

\section{Variables in the study}

\section{Hair mercury content}

Hair strands were cut at the occipital region, rolled around a cardboard with the root end fastened and placed in a paper envelope. The individual code of the subject was written on cardboard and on the paper envelope. Analyses of $\mathrm{H}-\mathrm{Hg}$ were carried out in the Laboratory of Environment Quality (LCA) of the Ecology Institute of La Paz University. Hair samples were rinsed in $0.01 \%$ EDTA. They were cut into small segments and mixed; analyses were performed on total length of the hair. A portion of $20 \mathrm{mg}$ of hair was digested using acids ( 2 volumes of $\mathrm{HNO}_{3}$ and 1 volume of $\left.\mathrm{H}_{2} \mathrm{SO}_{4}\right) ; \mathrm{KmnO}_{4}$ at $5 \%$ was added to oxidize the organic matter, and finally, samples were neutralized with hydroxylamine to obtain a crystalline solution. Measurements were performed using cold vapor coupled with atomic absorption spectrometry (Perkin Elmer $3110 \circledR$ ). Analyses were conducted in duplicate or triplicate. In case of a difference greater than $10 \%$ between measurements, a third analysis was performed. When this was not possible (not enough 
material for example), values were discarded. This was the case for 63 measurements. Mercury values were available for 556 subjects ( $88 \%$ of the subjects; 163 mothers and 393 children.

\section{Lifestyle of the communities}

We analyzed three variables to represent the living conditions of these populations. These variables were chosen from a larger set of socio-economic determinants. They displayed statistically significant associations with hair mercury content (Luna Monrroy 2007).

Economic activity. Families were divided into three groups: (i) predominance of farming and logging (some fishing activity); (ii) fishing as the main activity or coexisting with farming; (iii) wage-earning, storekeeping or handicrafts (no fishing activity).

Ethnic group. Mothers self-classified their families into one of the ethnic groups in the area: (i) Tacana (149 families); and (ii) Ese Ejjas (25 families).

Frequency of fish consumption. According to the mothers' answers, subjects were classified into three groups: (i) at least one serving of fish per person per day; (ii) less than one serving per day but at least one serving per week; (iii) less than one serving per week.

\section{Nutritional status}

This was ascertained on the basis of anthropometric measurements. The weight $(\mathrm{kg})$ was recorded with electronic Seca ${ }^{\circledR}$ scales accurate to $10 \mathrm{~g}$ in infants and to $100 \mathrm{~g}$ in older children and adults. Recumbent length was measured on a wooden board up until 2 years of age and standing height was measured with a Harpenden $®$ anthropometer thereafter. Measurements were taken according to recommended international techniques (Lohman et al. 1988).

The following subcutaneous skinfolds ( $\mathrm{mm}$ ) were recorded: Triceps, biceps, subscapular and supra-iliac skinfolds. Measurements were taken on the right side after marking the site on the skin with a Holtain $®$ caliper. Two successive measurements were performed and the average was used for analysis. The sum of the four skinfolds (sum 4 skf, mm) was used as an indicator of subcutaneous fat mass. Arm circumference was measured at mid-distance between the olecranon and acromion. Arm muscle circumference $(\mathrm{AMC}, \mathrm{cm})$ was calculated using the formula of Gurney and Jelliffe (Gurney and Jelliffe 1973): AMC = arm circumference- $\pi$ * (triceps skinfold).

Anthropometric indices of nutritional status were also calculated. Until 3 years of age, the new WHO reference data set was employed (WHO 2006). In older children, the classic WHO/CDC reference was used instead, with Anthro software (Centers for Disease Control and Prevention, Atlanta, GA, USA). The following nutritional indices were calculated: height-for-age (H-age, indicator of chronic malnutrition), weight-for-age (W-age, indicator of global malnutrition) and weight-for-height (W-H, indicator of acute malnutrition). Values were expressed as z-scores from the references.

Finally, the body mass index (BMI, $\mathrm{kg} / \mathrm{m}^{2}$ ) was computed as weight divided by the square of height and used as an index of corpulence in adolescents and adult women.

\section{Statistical analysis}

Data were entered and double-checked using Epi Info software. NCSS statistical software was employed (http://www.ncss.com/). All continuous variables were checked for normality of distribution. Appropriate transformations were done if necessary. Pearson correlation coefficients to test the association between $\mathrm{H}-\mathrm{Hg}$ and anthropometric indices were calculated. Multiple associations between mercury exposure, indicators of lifestyle and nutritional status 
were studied through a multiple regression procedure: a hierarchical model was run with a forward selection of variables. Main effects and two-way interaction terms were included. Normality of residual distribution and multicolinearity between variables were checked. 


\section{Results}

The median mercury hair content (H-Hg) was equal to $4.0 \mu \mathrm{g} / \mathrm{g}(\mathrm{CI} 95 \%: 3.6 \square 4.4 \mu \mathrm{g} / \mathrm{g})$. The distribution was asymmetric, with a heavy tail towards the right. The median was $4.4 \mu \mathrm{g} / \mathrm{g}$ for mothers and $3.9 \mu \mathrm{g} / \mathrm{g}$ for children, but the difference between medians was not statistically significant $(Z=1.03, p=0.30)$. A total of 78 subjects out of $556(14 \%)$ had values higher than $10 \mu \mathrm{g} / \mathrm{g}$. Among children and adolescents, there were no sex or age differences. After log natural transformation, the hypothesis of normality of $\mathrm{H}-\mathrm{Hg}$ distribution could be accepted.

Associations between $\mathrm{H}-\mathrm{Hg}$ and anthropometric indices were first assessed with Pearson correlation coefficients. Children were separated into three age groups: $0-5$ years old; 5 - to $10-$ years-old; and adolescents older than 10 years of age. Women were also studied separately. Results are displayed in Table 1. Two children had incomplete anthropometric data. No correlations between $\mathrm{H}-\mathrm{Hg}$ and nutritional status were evidenced in the younger age group or in adolescents. However, there existed significant and positive correlations among the 5 to 10 -yearolds between $\mathrm{H}-\mathrm{Hg}$ and $\mathrm{W}-\mathrm{H}, \mathrm{W}$-age and BMI. In women, there also existed significant correlations between BMI, AC, AMC and $\mathrm{H}-\mathrm{Hg}$, but contrary to children, they were negative.

Table 1: Correlation coefficients between anthropometric indices of nutritional status and mercury contamination ( $\mathrm{Log}$ natural of $\mathrm{H}-\mathrm{Hg}$ )

\begin{tabular}{|c|c|c|c|c|}
\hline $\begin{array}{l}\text { Nutritional } \\
\text { indices }^{1}\end{array}$ & $\begin{array}{c}0-5 \text { Years } \\
(n=134)\end{array}$ & $\begin{array}{c}5.1-10 \\
\text { Years } \\
(n=158)\end{array}$ & $\begin{array}{c}>10 \\
\text { Years } \\
(\mathrm{n}=99) \\
\end{array}$ & $\begin{array}{l}\text { Women } \\
(n=163)\end{array}$ \\
\hline H-age & $\begin{array}{c}0.02 \\
\text { ns }\end{array}$ & $\begin{array}{c}0.11 \\
\mathrm{~ns}\end{array}$ & $\begin{array}{c}-0.06 \\
\mathrm{~ns}\end{array}$ & \\
\hline $\mathrm{W}$-age & $\begin{array}{c}0.05 \\
\mathrm{~ns}\end{array}$ & $\begin{array}{l}0.17 \\
0.03\end{array}$ & $\begin{array}{c}-0.02 \\
\mathrm{~ns}\end{array}$ & \\
\hline W-H & $\begin{array}{c}0.03 \\
\mathrm{~ns}\end{array}$ & $\begin{array}{l}0.15 \\
0.06\end{array}$ & & \\
\hline BMI & $\begin{array}{c}-0.007 \\
\mathrm{~ns}\end{array}$ & $\begin{array}{l}0.20 \\
0.01\end{array}$ & $\begin{array}{c}0.05 \\
\mathrm{~ns}\end{array}$ & $\begin{array}{c}-0.19 \\
0.02\end{array}$ \\
\hline $\begin{array}{c}\text { Arm } \\
\text { circumference }\end{array}$ & $\begin{array}{c}-0.02 \\
\mathrm{~ns}\end{array}$ & $\begin{array}{c}0.02 \\
\mathrm{~ns}\end{array}$ & $\begin{array}{c}-0.01 \\
\mathrm{~ns}\end{array}$ & $\begin{array}{c}-0.19 \\
0.01\end{array}$ \\
\hline Sum 4 skf & $\begin{array}{c}0.00 \\
\mathrm{~ns}\end{array}$ & $\begin{array}{c}-0.08 \\
\mathrm{~ns}\end{array}$ & $\begin{array}{c}-0.12 \\
\mathrm{~ns}\end{array}$ & $\begin{array}{c}-0.22 \\
0.00\end{array}$ \\
\hline $\begin{array}{l}\text { Arm muscle } \\
\text { circumference }\end{array}$ & $\begin{array}{c}0.01 \\
\mathrm{~ns}\end{array}$ & $\begin{array}{c}0.09 \\
\mathrm{~ns}\end{array}$ & $\begin{array}{c}0.05 \\
\mathrm{~ns}\end{array}$ & $\begin{array}{c}-0.22 \\
\mathrm{~ns}\end{array}$ \\
\hline
\end{tabular}

1: H-age: height-for-age; W-age: weight-for-age; W-H: weight-for-height; BMI: body mass index; Sum 4 skf: sum of 4 skinfold thicknesses 
Figure 1 shows the magnitude of differences in anthropometric indices in the 5- to 10-year-olds after separation into two groups of exposure: low exposure (inferior to the first quartile of $\mathrm{H}-\mathrm{Hg}$ : $\leq 1.99 \mu \mathrm{g} / \mathrm{g}$ ) and high exposure (superior to the 4th quartile of $\mathrm{H}-\mathrm{Hg}: \geq 8.01 \mu \mathrm{g} / \mathrm{g}$ ). Differences were statistically significant for growth indices, including $\mathrm{H}$-age, W-age, W-H and BMI, but not for indices in adiposity and muscularity (sum $4 \mathrm{skf}$ and AMC). Mean differences were about 0.5 $\mathrm{z}$-scores for $\mathrm{H}$-age and $\mathrm{W}$-age. In women (Figure 2), mean differences in BMI were considerable between the 2 groups: $1.6 \mathrm{~kg} / \mathrm{m}^{2}$. They were close to $1.5 \mathrm{~cm}$ for AC and $8.5 \mathrm{~mm}$ for the $\mathrm{S} 4 \mathrm{skf}$. Differences in AMC were not significant.

To further elucidate the relationships between $\mathrm{H}-\mathrm{Hg}$ and anthropometric indices, multiple regression analyses were run separately in children and women, adding the three variables representing the lifestyle of communities: ethnic group (considered as a cultural and social marker); fish consumption (frequency of fish servings); and subsistence mode (including or not fishing) considered as a risk factor.

Table 2 displays the results of 5- to 10 -year-old children. There existed substantial multicolinearity between the BMI and the W-H index. In consequence, W-H was dropped. The model was pertinent $(\mathrm{F}=12.1, p<0.0001)$ and explained an appreciable fraction of variability in $\mathrm{H}-\mathrm{Hg}\left(\mathrm{R}^{2}=0.37\right)$. BMI and $\mathrm{H}$-age still continued to be significantly associated with $\mathrm{H}-\mathrm{Hg}$, independently of the effects of other variables. Belonging to the Ese Ejjas ethnic group and fishing as a primary or secondary subsistence activity were also associated with elevated mercury concentration. In contrast, consumption of less then one serving per day or exercising a profession not connected with river or land use, were protective factors against mercury exposure.

\section{Table 2}

Multiple regression analysis between $\mathrm{H}-\mathrm{Hg}$ (log natural), nutritional status and family characteristics in 5-10-year-old children

\begin{tabular}{|c|c|c|c|c|c|}
\hline $\begin{array}{l}\text { Independent } \\
\text { Variable } 1 \\
\end{array}$ & $\begin{array}{l}\text { Regression } \\
\text { coefficient }\end{array}$ & $\begin{array}{c}\text { Standard } \\
\text { error }\end{array}$ & t-value & p value & Partial $\mathbf{R}^{22}$ \\
\hline $\mathrm{BMI}$ & 0.14 & 0.05 & 2.73 & 0.01 & 0.05 \\
\hline Ethnicity=Ese Ejjas & 0.69 & 0.22 & 3.14 & 0.00 & 0.06 \\
\hline H-age & 0.14 & 0.06 & 2.49 & 0.01 & 0.04 \\
\hline Fish consumption & & & & & \\
\hline $\begin{array}{l}\text { (1 Serving per week) } \\
(<1 \text { Serving per }\end{array}$ & -0.37 & 0.17 & -2.19 & 0.03 & 0.03 \\
\hline week) & -0.61 & 0.20 & -2.96 & 0.00 & 0.06 \\
\hline $\begin{array}{l}\text { Economic activity } \\
\text { (including fishing) }\end{array}$ & 0.64 & 0.15 & 4.30 & 0.00 & 0.11 \\
\hline (excluding fishing) & -0.33 & 0.24 & -1.35 & 0.18 & 0.01 \\
\hline
\end{tabular}

${ }^{1}$ BMI: body mass index; H-age: height-for-age

${ }^{2}$ Partial $\mathrm{R}^{2}$ after adjusting for effects of all other variables 
In women (Table 3), the picture differed in that anthropometric indices were no longer significant predictors of $\mathrm{H}-\mathrm{Hg}$ when lifestyle variables were taken into account. The model was pertinent $(\mathrm{F}=7.12, p<0.001)$, explaining a smaller fraction of variability in $\mathrm{H}-\mathrm{Hg}$ than in children $\left(R^{2}=0.28\right)$. There was a significant relationship between ethnicity (belonging to the Ese Ejjas group) and $\mathrm{H}-\mathrm{Hg}$. Fishing activity also was linked to $\mathrm{H}-\mathrm{Hg}$, and eating less than one serving of fish per day had a protective effect on mercury exposure (negative sign of regression coefficients).

\section{Table 3}

Multiple regression analysis between $\mathrm{H}-\mathrm{Hg}$ (log natural), nutritional status and family characteristics in adult women

\begin{tabular}{|c|c|c|c|c|c|}
\hline $\begin{array}{l}\text { Independent } \\
\text { Variable }{ }^{1} \\
\end{array}$ & $\begin{array}{c}\text { Regression } \\
\text { coefficient }\end{array}$ & $\begin{array}{c}\text { Standard } \\
\text { error }\end{array}$ & t-value & Prob & $\operatorname{Partial}\left(\mathbf{R}^{\mathbf{2}}\right)^{2}$ \\
\hline BMI & 0.03 & 0.04 & 0.66 & 0.51 & 0.003 \\
\hline Ethnicity=Ese Ejjas & 0.51 & 0.20 & 2.57 & 0.01 & 0.043 \\
\hline Arm circumference & 0.00 & 0.04 & 0.07 & 0.94 & 0.000 \\
\hline $\begin{array}{l}\text { Fish consumption } \\
\text { (1 serving per week) } \\
(<1 \text { serving per }\end{array}$ & -0.44 & 0.15 & -2.87 & 0.00 & 0.053 \\
\hline week) & -0.42 & 0.19 & -2.17 & 0.03 & 0.031 \\
\hline $\begin{array}{l}\text { Economic activity } \\
\text { (including fishing) }\end{array}$ & 0.47 & 0.14 & 3.37 & 0.00 & 0.071 \\
\hline (excluding fishing) & -0.26 & 0.20 & -1.31 & 0.19 & 0.012 \\
\hline Sum 4 skf & -0.01 & 0.01 & -0.85 & 0.40 & 0.005 \\
\hline
\end{tabular}

${ }^{1}$ BMI: body mass index; Sum 4 skf: sum of 4 skinfold thicknesses

${ }^{2}$ Partial $\mathrm{R}^{2}$ after adjusting for effects of all other variables 


\section{Discussion}

The low hair mercury content reported here may be regarded as the signature of fish consumption instead of a health threat for the population. This finding explains why a positive relationship was found between $\mathrm{H}-\mathrm{Hg}$, and a relatively better nutritional status in the 5- to 10year-old children. Surprisingly, the opposite was observed in adult women: the most exposed mothers displayed worse nutritional indices than non-contaminated mothers.

It should be mentioned that this study presents limitations. It was based on a cross-sectional survey; variability over time and across communities could not be ascertained. It was restrained to a specific area of the foothills of the Andes and thus did not depict the overall situation of the Beni River valley. Communities were small, dispersed along the banks and difficult to reach. However, one of the strengths of this study is that it compared two different communities living in the same area, but displaying contrasted exposures. The same design and methods were applied to all subjects, and the sample structure was similar. This is the first study to include a fairly large sample and which focuses on a public health perspective in Bolivia.

Some explanations can be thus proposed to clarify the main findings. It is possible that the age group of children in whom nutritional indices correlated with $\mathrm{H}-\mathrm{Hg}$ represented a period of growth more sensitive to nutrient intake provided by fish than that of younger children. Indeed, the growth pattern of preschoolers was severely depressed by infectious and parasitic diseases prevalent in the area (Benefice et al. 2006). In another closely related Amerindian tribe, the Tsimane', and using CRP as an indicator of pathogen exposure, it was shown that the younger children presented a high degree of immune stimulation and were the most severely infected (McDade et al. 2005). It could be hypothesized that, in children younger than 5-years-old, the favorable effect of a fish-based diet was challenged by the high metabolic cost of inflammation and infections. Eventually, maturation of their immune system would allow the older children to divert more nutrients toward growth requirements (McDade 2005). In connection with this, it could be observed that in the study area, clear-cut nutritional depression occurred after the weaning period, followed by partial recovery (Benefice et al. 2006).

The absence of a relationship between anthropometry and $\mathrm{H}-\mathrm{Hg}$ in adolescents is more difficult to explain. First, this result could be due to a sampling effect: not all adolescents were present in the villages during our visits. Most were working with their fathers in the forest or were attending middle schools in nearby towns. Secondly, the control of growth during puberty, especially age at take-off and peak velocity of the growth spurt, may be less responsive to environmental and nutritional influences and more sensitive to ethnic and genetic features (Parent et al. 2003).

When relationships between $\mathrm{H}-\mathrm{Hg}$ and anthropometric indices of nutrition were reexamined taking into account the effect of variables representing lifestyle, a significant impact of BMI and $\mathrm{H}$-age persisted for $\mathrm{H}-\mathrm{Hg}$ variance. This was not the case for the other indices. Obviously, this did not demonstrate a causal relationship. Other variables (belonging to the Ese Ejjas group and fishing) were also significant predictors. In addition, consumption of less than one serving of fish per day had a protective effect on $\mathrm{H}-\mathrm{Hg}$. This strongly suggests that fish consumption is the intermediate link. In Brazil, Dorea and colleagues, in a recent paper, considered that $\mathrm{H}-\mathrm{Hg}$ could serve as a biomarker of fish consumption in the Munduruku and Kayabi groups living along the Tapajo River (Dorea et al. 2005b). In their paper, the authors insist on the fact that fish is a nutritionally important and abundant resource for the Amerindian people. They underlined that no harmful effect associated with $\mathrm{H}-\mathrm{Hg}$ was discernible and that tropical diseases were more 
frightening for this Amerindian tribe. In another paper, the same team tried to demonstrate a positive effect on growth of fish consumption, judged from $\mathrm{H}-\mathrm{Hg}$. They failed to demonstrate a consistent pattern as we did here (Dorea et al. 2005a). This may be due to the fact that they did not segregate their population into different age groups. The important point is that in growing children with mild exposure to mercury, the advantage of a fish-based diet might overcome the risk of exposure. This is not to dismiss the toxicity of the mercury but simply to emphasize the importance of the social, economic and ecological context in which the children were growing up. In a similar manner, the proposed safe upper limit of $340 \mathrm{~g}$ of seafood intake per week by pregnant mothers in the USA has been recently discussed and criticized (Hibbeln et al. 2007). In contradiction with this recommendation, the authors reported better neurodevelopment outcome in children of mothers who consumed more than $340 \mathrm{~g}$ of fish per week. This is an important issue which has not been completely resolved. Conclusions of a longitudinal study carried out in the Seychelles, despite some recent 'smoothing' (van Wijngaarden et al. 2006), diverge somewhat from those of the survey performed in the Faroe Islands (Debes et al. 2006). Uncertainties remain in evaluating the developmental risk of in utero exposure to methylmercury. They were pointed out in a recent review paper (Spurgeon 2006). Because of these inconsistencies, the threat of mercury exposure must be analyzed in the face of the overall health burden and likely socio-cultural perturbations caused by measures aimed at lessening fish consumption (Wheatley and Wheatley 2000).

Women displayed a clearly different profile compared with children. Correlation coefficients between $\mathrm{H}-\mathrm{Hg}$ and anthropometry were negative. Moreover, the association disappeared when other factors were entered into a multivariate model. The apparent effect of anthropometric indices was, in fact, due to differences in lifestyle and genetic and cultural features represented by ethnicity. Indeed, we previously demonstrated that differences in body size existed between Tacana and Ese Ejja mothers: Ese Ejjas were shorter, lighter and had significantly less fat mass than the Tacana women. However, and more importantly, differences disappeared when health status, subsistence activity and dietary intakes were taken into account (Benefice et al. 2007). Indeed, ethnicity may be considered as a social and cultural indicator, but did not carry here any explanative power per se when other factors were considered. As a matter of fact, Ese Ejjas and Tacanas are very closely related groups and their history diverged only recently. An important question then arises: why was the positive effect on nutritional status of $\mathrm{H}-\mathrm{Hg}$ not discernible in women as it was in children? First, it should be noted that the most severely contaminated women belonged mainly to the Ese Ejjas group characterized by a semi-nomadic style of life and substantial vulnerability in terms of access to health centers, obstetric and medical attendance and pre- and postnatal care. They also are prey to climatic and natural risks (heavy rains, flooding) and periods of uncertainty as to available food (Benefice et al. 2006). Second, constraints due to physical and environmental influences do not work uniformly from infancy to adulthood. It is certain that different components of body composition and body size respond in different ways to environmental and genetic factors during life history (Pietilainen et al. 2002). A predictor of satisfactory nutritional status during childhood (fish consumption) may turn into an indicator of vulnerability and hazardous style of life later on during adulthood.

Because of the entanglement of causes and consequences of biological and cultural effects of mercury exposure, a more in-depth anthropological analysis of the situation would have been useful. It is thus, difficult to draw firm conclusions. However, two important issues emerge from this study. First, H-Hg exposure is moderate at the moment compared with other situations observed in the Brazilian Amazon (Dorea et al. 2005b). Nonetheless, mercury is an element that will not disappear by itself and will continue to biomagnify and bioaccumulate, eventually causing major environmental prejudice to the few surviving Amerindian communities. A regular 
assessment of the level of contamination of the most frequently consumed fish species is required. Second, any advice aimed at reducing fish consumption by Amerindian communities should be weighed in the face of the lifestyle of these people (Wheatley and Paradis 1996; Wheatley and Wheatley 2000). The advantage conferred by food with high nutritional value for growing children must be emphasized (Dorea et al. 2003). Symptoms suggestive of Minamata disease have not been found in the Amazon (Dorea 2004). Yet other teams of researchers disagree and point to a neurological impact at low levels of exposure (Lebel et al. 1998; Grandjean et al. 1999). However, it could be observed that they did not take into account other health hazards (anemia, malnutrition, infectious diseases) known to impair the neuromotor development of children. Such factors of confusion were mentioned by Dorea (2004) and Grandjean et al. (1999).

\section{Conclusion}

Fish consumption and concomitant mercury exposure in Amazonian Bolivia has important nutritional implications, but its impact upon health remains to be studied. Policies aimed at lessening mercury exposure must contemplate several points of view (public health, anthropological and ecological features) and should not be limited to one aspect of the problem. 


\section{Acknowledgements}

We warmly thank the riverside communities of the Beni River for their kind cooperation. We are indebted to the LCA team (Environmental Quality Laboratory, Institute of Ecology, Universidad Mayor de San Andrès, La Paz, Bolivia) namely Lucia Alanoca, Vania Garcia and Jaime Chincherros (director) for their help in the determination of hair mercury content. We also thank our colleagues of the SELADIS (Sonia Jimenez, Mariluz Soto, Susana Revollo and Sara Perez, directora) for their constant support and help during the surveys. This paper is a tribute to our colleague Marc Roulet ( $\uparrow 2006)$ who inspired and coordinated the ATI research program. The research was sponsored by Research Unit 024, Epidemiology and Prevention, IRD, France; Action Thématique Interdépartementale (ATI); Usage des Sols et des Sédiments; and Impact Sanitaire, IRD, France. 


\section{References}

1. Anónimo (2005) Diagnóstico Socioeconómico, Zona 3: Norte Amazónico p. 200. DHVANR, BV , La Paz

2. Benefice, E., Lopez, R., Monroy, S. L. and Rodriguez, S. (2007) Fatness and overweight in women and children from riverine Amerindian communities of the Beni River (Bolivian Amazon). Am J Hum Biol 19:1, pp. 61-73.

3. Benefice, E., Monroy, S. L., Jimenez, S. and Lopez, R. (2006) Nutritional status of Amerindian children from the Beni River (lowland Bolivia) as related to environmental, maternal and dietary factors. Public Health Nutr 9:3, pp. 327-335.

4. Branches, F. J., Erickson, T. B., Aks, S. E. and Hryhorczuk, D. O. (1993) The price of gold: mercury exposure in the Amazonian rain forest. $J$ Toxicol Clin Toxicol 31:2, pp. 295-306.

5. Buitron, D., Hurtig, A. K. and San Sebastian, M (2004) [Nutritional status of Naporuna children under five in the Amazon region of Ecuador]. Rev Panam Salud Publica 15:3, pp. 151-159.

6. Debes, F., Budtz-Jorgensen, E., Weihe, P., White, R. F. and Grandjean, P. (2006) Impact of prenatal methylmercury exposure on neurobehavioral function at age 14 years. Neurotoxicol Teratol 28:3, pp. 363-375.

7. Dorea, J. G. (2003) Fish are central in the diet of Amazonian riparians: Should we worry about their mercury concentrations?. Environ Res 92:3, pp. 232-244.

8. Dorea, J. G. (2004) Cassava cyanogens and fish mercury are high but safely consumed in the diet of native Amazonians. Ecotoxicol Environ Saf 57:3, pp. 248-256.

9. Dorea, J., Barbosa, A. C., Ferrari, I. and de Souza, J. R. (2003) Mercury in hair and in fish consumed by Riparian women of the Rio Negro, Amazon, Brazil. Int J Environ Health Res 13:3, pp. 239-248.

10. Dorea, J. G., Barbosa, A. C., Ferrari, I. and De Souza, J. R. (2005a) Fish consumption (hair mercury) and nutritional status of Amazonian Amer-Indian children. Am J Hum Biol 17:4, pp. 507-514.

11. Dorea, J. G., de Souza, J. R., Rodrigues, P., Ferrari, I. and Barbosa, A. C. (2005b) Hair mercury (signature of fish consumption) and cardiovascular risk in Munduruku and Kayabi Indians of Amazonia. Environ Res 97:2, pp. 209-219.

12. Dufour, D. L. (1991) Diet and nutritional status of Ameridians: A review of the literature. Cad Saude Publica 7:4, pp. 481-502.

13. Dufour, D. (1992) Nutritional ecology in the tropical forests of Amazonia. Am J Human Biol 4 , pp. 197-207.

14. Foster, Z., Byron, E., Reyes-Garcia, V., Huanca, T., Vadez, V., Apaza, L., Perez, E., Tanner, S., Gutierrez, Y. Sandstrom, B. et al. (2005) Physical growth and nutritional status of Tsimane' Amerindian children of lowland Bolivia. Am J Phys Anthropol 126:3, pp. 343-351.

15. Gilbert, S. G. and Grant-Webster, K. S. (1995) Neurobehavioral effects of developmental methylmercury exposure. Environ Health Perspect 103:Suppl 6, pp. 135-142. 
16. Grandjean, P., White, R. F., Nielsen, A., Cleary, D. and de Oliveira Santos, E C (1999) Methylmercury neurotoxicity in Amazonian children downstream from gold mining. Environ Health Perspect 107:7, pp. 587-591.

17. Gurney, J. M. and Jelliffe, D. B. (1973) Arm anthropometry in nutritional assessment: Nomogram for rapid calculation of muscle circumference and cross-sectional muscle and fat areas. Am J Clin Nutr 26:9, pp. 912-915.

18. Hibbeln, J. R., Davis, J. M., Steer, C., Emmett, P., Rogers, I., Williams, C. and Golding, J. (2007) Maternal seafood consumption in pregnancy and neurodevelopmental outcomes in childhood (ALSPAC study): An observational cohort study. Lancet 369:9561, pp. 578-585.

19. Lebel, J., Mergler, D., Branches, F., Lucotte, M., Amorim, M., Larribe, F. and Dolbec, J. (1998) Neurotoxic effects of low-level methylmercury contamination in the Amazonian Basin. Environ Res 79:1, pp. 20-32.

20. Lohman, T. G., Roche, A. and Martorell, R. (1988) Anthropometric standardization reference manual p. 177. Human Kinetics Books, Champaign, IL

21. Luna Monrroy, S X (2007) Exposición a mercurio de mujeres y niños de comunidades indí genas del río Beni (Bolivia), con relación a problemas de salud (malmutrición, parasitismo, anemia) endémicos en el área. [Master of Scien p. 102. Mayor de San Andres University, La Paz

22. Malm, O., Branches, F. J., Akagi, H., Castro, M. B., Pfeiffer, W. C., Harada, M., Bastos, W. R. and Kato, H. (1995) Mercury and methylmercury in fish and human hair from the Tapajos river basin, Brazil. Sci Total Environ 175:2, pp. 141-150.

23. Maurice-Bourgoin, L. and Quiroga, I. (2002) Total mercury distribution and importance of the biomagnification process in rivers of the Bolivian Amazon. Chapter 4. The ecohydrology of South American rivers and Wetlands. IAHS Special Publication 6 , pp. 49-67.

24. Maurice-Bourgoin, L., Quiroga, I., Chincheros, J. and Courau, P. (2000) Mercury distribution in waters and fishes of the upper Madeira rivers and mercury exposure in riparian Amazonian populations. Sci Total Environ 260:1-3 , pp. 73-86.

25. McDade, T. W. (2005) Life history, maintenance, and the early origins of immune function. Am J Hum Biol 17:1, pp. 81-94.

26. McDade, T. W., Leonard, W. R., Burhop, J., Reyes-Garcia, V., Vadez, V., Huanca, T. and Godoy, R. A. (2005) Predictors of C-reactive protein in Tsimane' 2- to 15-year-olds in lowland Bolivia. Am J Phys Anthropol 128:4, pp. 906-913.

27. Parent, A. S., Teilmann, G., Juul, A., Skakkebaek, N. E., Toppari, J. and Bourguignon, J. P. (2003) The timing of normal puberty and the age limits of sexual precocity: Variations around the world, secular trends, and changes after migration. Endocr Rev 24:5, pp. 668693.

28. Pietilainen, K. H., Kaprio, J., Rasanen, M., Rissanen, A. and Rose, R. J. (2002) Genetic and environmental influences on the tracking of body size from birth to early adulthood. Obes Res 10:9 , pp. 875-884.

29. Ribas, D. L., Sganzerla, A., Zorzatto, J. R. and Philippi, S. T. (2001) [Child health and nutrition in a Terena indigenous community, Mato Grosso do Sul, Brazil]. Cad Saude Publica 17:2, pp. 323-331. 
30. Roos, N., Wahab, M. A., Chamnan, C. and Thilsted, S. H. (2007) The role of fish in food-based strategies to combat vitamin A and mineral deficiencies in developing countries. J Nutr 137:4, pp. 1106-1109.

31. Simopoulos, A. P. (1991) Omega-3 fatty acids in health and disease and in growth and development. Am J Clin Nutr 54:3, pp. 438-463.

32. Spurgeon, A. (2006) Prenatal methylmercury exposure and developmental outcomes: review of the evidence and discussion of future directions. Environ Health Perspect 114:2, pp. 307-312.

33. United Nations Environment Program (UNEP) (2002) Global mercury assessment p. 258. UNEP - Chemicals, Geneva

34. van Wijngaarden, E., Beck, C., Shamlaye, C. F., Cernichiari, E., Davidson, P. W., Myers, G. J. and Clarkson, T. W. (2006) Benchmark concentrations for methyl mercury obtained from the 9-year follow-up of the Seychelles child development study. Neurotoxicology 27:5, pp. 702-709.

35. Wheatley, B. and Paradis, S. (1996) Balancing human exposure, risk and reality: Questions raised by the Canadian aboriginal methylmercury program. Neurotoxicology 17:1, pp. 241-249.

36. Wheatley, B. and Wheatley, M. A. (2000) Methylmercury and the health of indigenous peoples: A risk management challenge for physical and social sciences and for public health policy. Sci Total Environ 259:1-3 , pp. 23-29.

37. WHO (World Health Organization) (2006) WHO child growth standards: Length heightfor-age, weight-for-age, weight-for-length, weight-for-height and body mass index-forage: methods and development p. 336. WHO, Geneva 

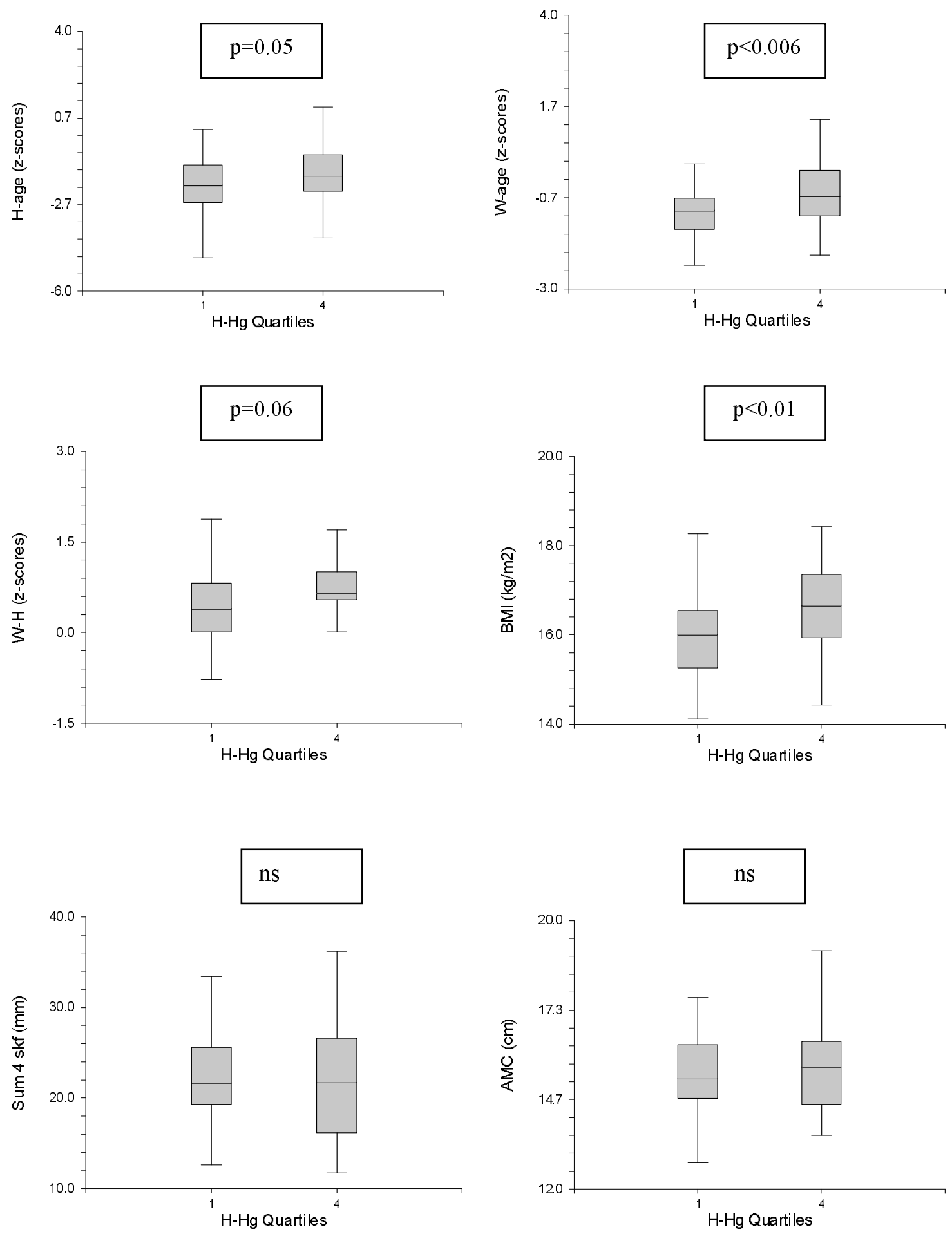

Figure 1: Contrasts in anthropometric indices between 5.1-10-year-old children belonging to the $1^{\text {st }}$ and $4^{\text {th }}$ quartile of $\mathrm{H}-\mathrm{Hg}$

$$
\mathrm{p}<0.03
$$$$
p<0.02
$$ 

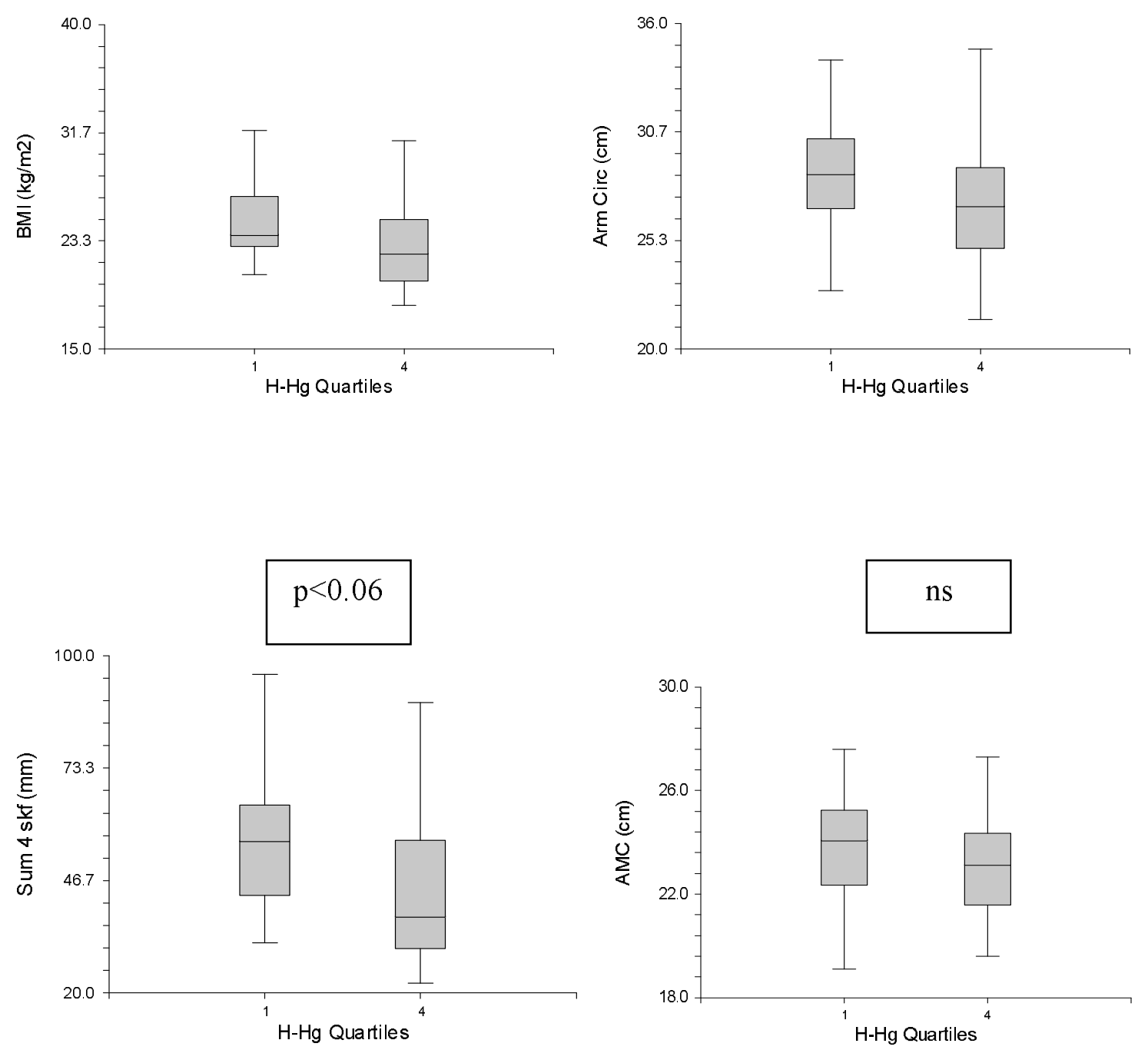

Figure 2: Contrasts in anthropometric indices between women belonging to the $1^{\text {st }}$ and $4^{\text {th }}$ quartile of $\mathrm{H}-\mathrm{Hg}$ 